\title{
Subsidence monitoring with geotechnical instruments in the Mexicali Valley, Baja California, Mexico
}

\author{
E. Glowacka ${ }^{1}$, O. Sarychikhina ${ }^{1}$, V. H. Márquez Ramírez ${ }^{2}$, B. Robles ${ }^{3}$, F. A. Nava ${ }^{1}$, F. Farfán ${ }^{1}$, and \\ M. A. García Arthur ${ }^{1}$ \\ ${ }^{1}$ Centro de Investigacion Cientifica y Educacion Superior de Ensenada, Ensenada, Mexico \\ ${ }^{2}$ UNAM Campus, Centro de Geociencias, Juriquilla, Querétaro, Mexico \\ ${ }^{3}$ Instituto Mexicano de Tecnología de Agua, Jiutepec, Morelos, Mexico
}

Correspondence to: E. Glowacka (glowacka@ cicese.mx)

Published: 12 November 2015

\begin{abstract}
The Mexicali Valley (northwestern Mexico), situated in the southern part of the San Andreas fault system, is an area with high tectonic deformation, recent volcanism, and active seismicity. Since 1973, fluid extraction, from the 1500-3000 m depth range, at the Cerro Prieto Geothermal Field (CPGF), has influenced deformation in the Mexicali Valley area, accelerating the subsidence and causing slip along the traces of tectonic faults that limit the subsidence area. Detailed field mapping done since 1989 (González et al., 1998; Glowacka et al., 2005; Suárez-Vidal et al., 2008) in the vicinity of the CPGF shows that many subsidence induced fractures, fissures, collapse features, small grabens, and fresh scarps are related to the known tectonic faults. Subsidence and fault rupture are causing damage to infrastructure, such as roads, railroad tracks, irrigation channels, and agricultural fields.

Since 1996, geotechnical instruments installed by CICESE (Centro de Investigación Ciéntifica y de Educación Superior de Ensenada, B.C.) have operated in the Mexicali Valley, for continuous recording of deformation phenomena. Instruments are installed over or very close to the affected faults. To date, the network includes four crackmeters and eight tiltmeters; all instruments have sampling intervals in the 1 to 20 min range.

Instrumental records typically show continuous creep, episodic slip events related mainly to the subsidence process, and coseismic slip discontinuities (Glowacka et al., 1999, 2005, 2010; Sarychikhina et al., 2015).

The area has also been monitored by levelling surveys every few years and, since the 1990's by studies based on DInSAR data (Carnec and Fabriol, 1999; Hansen, 2001; Sarychikhina et al., 2011).

In this work we use data from levelling, DInSAR, and geotechnical instruments records to compare the subsidence caused by anthropogenic activity and/or seismicity with slip recorded by geotechnical instruments, in an attempt to obtain more information about the process of fault slip associated with subsidence.
\end{abstract}

\section{Introduction}

The Mexicali Valley is located, in the southern part of the San Andrés fault system, within the southern part of the Salton Trough, on the border between the North America and Pacific tectonic plates. The Valley is characterized by recent volcanic hydrothermal processes, active tectonics, and high seismicity. Moreover large earthquakes concentrate along the major, Imperial and Cerro Prieto faults, while scattered seismicity, (mainly swarms), and deformation are observed in the Pull-apart Cerro Prieto Basin (Lomnitz et al., 1970; Nava and Glowacka, 1994; Suárez-Vidal et al., 2008). Fluid extraction began in the Cerro Prieto Geothermal Field (CPGF) in 1973, and brine injection therein began in 1989; these processes have been influencing deformation, stress, and seismicity of the area (Majer and McEvilly, 1981; Glowacka and Nava, 1996; Fabriol and Munguía, 1997; Glowacka et al., 1999, 2005; Trugman et al., 2014).

The subsidence area is limited to the area between the Imperial, Saltillo, Cerro Prieto and Morelia faults (Fig. 1). This zone, also known as Cerro Prieto basin, is larger than 


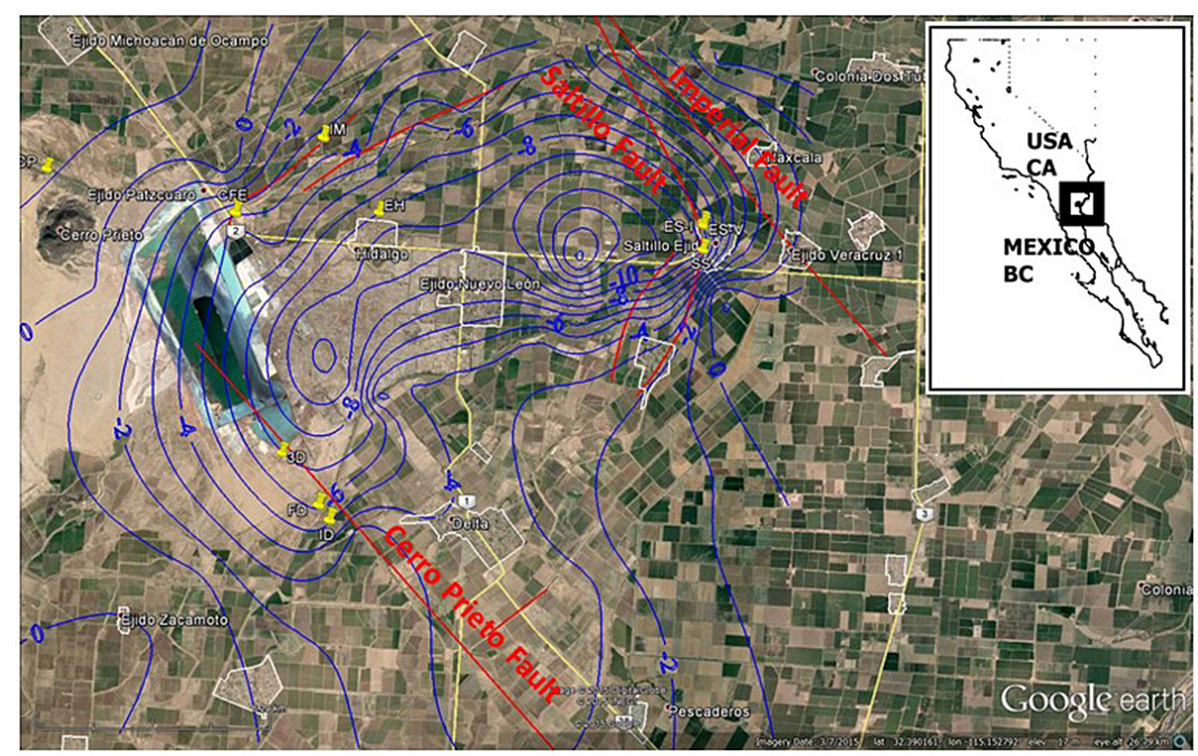

Figure 1. Instruments (yellow pins) and the subsidence rate blue isolines ( $\mathrm{cm} \mathrm{yr}^{-1}$ ) for 1997-2006 (modified from Glowacka et al., 2011). Red lines indicate tectonic faults. The inset shows the geographical location of the study area.

the extraction zone, suggesting the existence of a recharging region. Since the sunken area is limited by tectonic faults, Glowacka et al. (1999, 2005, 2010a), suggest that these faults constitute a boundary of the subsiding region, due to differential compaction and/or due to poor permeability in the direction perpendicular to the faults that acts as a groundwater barrier.

The CPGF has $720 \mathrm{MW}$ production capacity, or $1 / 3$ of electricity production in Baja California; however, the anthropogenic subsidence caused by deep extraction of fluids in the CPGF causes damage to roads, railways and irrigation systems, increasing the natural hazards in this area that is quite vulnerable because of its tectonic situation.

The history of subsidence at the CPGF area has been well documented. Geodetic studies in the Mexicali Valley began in the 1960's. Leveling surveys have been done in the area of the CPGF and the Mexicali Valley since 1977 (Velasco, 1963; Lira and Arellano, 1997; Glowacka et al., 1999, 2012). Subsidence in the CPGF has also been measured via DInSAR (Differential Synthetic Aperture Radar Interferometry) by Carnec and Fabriol (1999) and Hanssen (2001) using ERS1/2 images acquired during 1993-1997 and 1995-1997, respectively, and interpreted as an anthropogenic effect of fluid extraction.

Sarychikhina et al. (2011) applied the DInSAR technique using C-band ENVISAR ASAR data acquired between 2003 and 2006, to determine the extent and amount of land subsidence in the Mexicali Valley near the CPGF. Recently Sarychikhina et al. (2015) applied DInSAR technique, together with leveling results and geotechnical instruments data and modeling, to estimate seismic and aseismic deformation in Mexicali Valley for the period 2006-2009. The cur- rent subsidence rate, evaluated from DInSAR data is of the order of $12 \mathrm{~cm} \mathrm{yr}^{-1}$ in the production area and $18 \mathrm{~cm} \mathrm{yr}^{-1}$ for the recharging zone (Sarychikhina et al., 2015; Sarychikhina and Glowacka, 2015a).

\section{Geotechnical instruments monitoring}

To study the spatial and temporal distribution of crustal deformation in the Mexicali Valley, CICESE installed a network of geotechnical instruments, starting in 1996. Since then, the REDECVAM (Red de Deformaciones de la Corteza en el Valle de Mexicali) network has included four creepmeters (wide range extensometer) and nine tiltmeters installed over different periods in different places; all instruments have sampling intervals in the 1 to $20 \mathrm{~min}$ range (Nava and Glowacka, 1999; Glowacka et al., 2002, 2010b, c; Sarychikhina et al., 2015). Creepmeters (Geokon model 4420 ) were installed mainly on vertical planes perpendicular to faults, in order to record vertical displacement. Biaxial tiltmeters (Applied Geomechanics, models 711, 712, and 722) were installed in shallow vaults or wells, close to faults.

Data from a creepmeter and a tiltmeter installed on the Saltillo fault (Fig. 1) show fault vertical displacement rate at $\sim 5.3 \mathrm{~cm} \mathrm{yr}^{-1}$ until 2003 and $\sim 7.3 \mathrm{~cm} \mathrm{yr}^{-1}$ since then. The distance-time relationship between changes in extraction at the CPGF and the displacement rate change found at the Saltillo fault suggests that the fault is probably affected by extraction through diffusive transmission of pore pressure changes, with a characteristic hydraulic diffusivity (Glowacka et al., 2010a).

Vertical displacement at the Saltillo fault consists of continuous creep and episodic slip events, sometimes concen- 

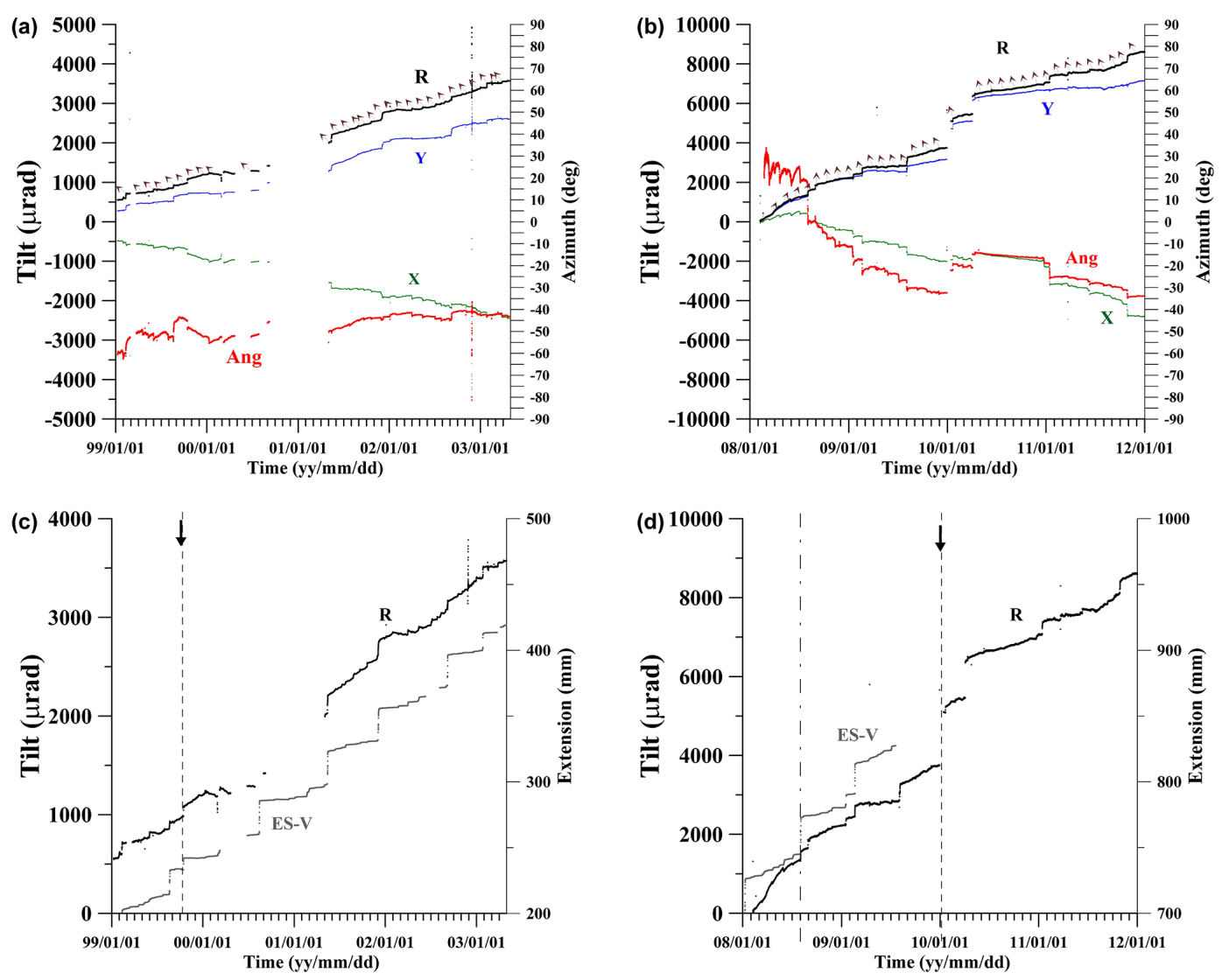

Figure 2. Tilt observations. $X$ and $Y$ are the East-West and North-South components of tilt, respectively, and $R$ is the resultant tilt magnitude in the azimuth direction, Ang, for 1999-2003 (a) and 2003-2012 (b). $X, Y$ and $R$ are referred to the left axes, while azimuth Ang is referred to the right axes. Azimuth is also shown by the direction in which brown arrowheads point, with North straight up. Extension ES-V and magnitude $R$ for 1999-2003 (c) and 2008-2012 (d). The vertical arrow indicates the $M=7.2$ hector Mine earthquake in (c), and $M=5.8$ 2009 earthquake in (d). The dotted-line indicates slip event in August 2008.

trated in suites (Nava and Glowacka, 1999). Episodic slips have 1 to $3 \mathrm{~cm}$ magnitudes and 1-3 days duration, separated by months of monotone creep, and release about $50 \%$ of total slip. The episodic fault slip in the Saltillo fault appears mainly as slip-predictable, normal, aseismic slip (e.g. Glowacka et al., 2001, 2010a). Using reservoir model, geological structure, and subsidence data, Glowacka et al. (2010a), speculatively proposed the depth range of slip events to be from 1 to $2.5 \mathrm{~km}$.

Some of the slip events are triggered by distant earthquakes. This includes, for example, Hector Mine Earthquake (of magnitude 7.2 and at a distance $260 \mathrm{~km}$ away 15 on 1999), as described by Glowacka et al. (2002), and, probably, by the Canal de las Ballenas earthquake (of magnitude 6.9 and a distance $\sim 400 \mathrm{~km}$ away 2009 ), as described by Glowacka et al. (2015). These studies suggest that distant earthquakes can influence fault slip related to the subsidence. Both, sporadic and triggered slip events confirm slip predictable fault behavior.
Detailed analysis of tiltmeter and creepmeter data done by Sarychikhina et al. (2015), identified which part of subsidence observed by DInSAR in the Mexicali valley during 2006-2009 was caused by local seismicity. Glowacka et al. (2015) estimated that during the 2006-2009 period of relatively high seismicity, the anthropogenic subsidence was of the order of $80 \%$ of the total subsidence, which is close to estimates done by Glowacka et al. (2005), Camacho Ibarra (2006), and Sarychikhina et al. (2015).

The goal of this paper is to find if there are differences, in the signal characteristics observed on the creepmeter and/or tiltmeter records, between continuous creep, sporadic slip, triggered slip and coseismic slip recorded on the Saltillo fault.

\section{Results}

In the following we will analyze records from ES-V creepmeter and ES-I biaxial tiltmeter installed very close to each other on the Saltillo fault. A biaxial tiltmeter (ES-I) was in- 
stalled in 1998, very close to the creepmeter and recorded ground tilt until 2003 (Fig. 2a), and after a small reconstruction, again since 2008 (Fig. 2b). E-W $(X)$ and N-S $(Y)$ inclination recorded on ES-I tiltmeter are presented on Fig. 2a (1999-2003) and Fig. 2b (2008-2012).

For the tilt we calculate the resultant magnitude, $R$, and the azimuth, Ang, as

$R=\left(X^{2}+Y^{2}\right)^{1 / 2}$

$\operatorname{Ang}=\arctan (\Delta X / \Delta Y)$,

where $X$ and $Y$ are the measured tilts in the $\mathrm{N}-\mathrm{S}$ and E-W directions, respectively; $\Delta X=X \cos \theta+Y \sin \theta$, and $\Delta Y=Y \cos \theta-X \sin \theta$, and $\theta$ is the correction for the azimuth orientation of the $\mathrm{Y}$ axis from North. $\theta=-10^{\circ}$ for ES-I.

The tilt magnitude, $R$, and the ES-V vertical extension recorded by the creepmeter, are shown in Fig. 2c (19992003) and Fig. 2d (2008-2012).

Figure 3 shows $R$ and Ang for the August 2008 slip episode (Fig. 3a), the slip event triggered by the $M=7.2$ Hector Mine earthquake (Fig. 3b) and by the local $M=5.8$, 30 December 2009, earthquake (Fig. 3c). While episodic slip events and triggered slip events show very similar behavior of $R$ and Ang, the slip related to the 5.8 local earthquake has different behavior.

\section{Discussion}

Figure $2 \mathrm{c}$ and $\mathrm{d}$ show $R$ and creepmeter extension ES-V observed between 1999-2003 and 2008-2012, respectively. The similarity between $R$ and ES-V seen on both Fig. 2 suggests that tilt increases when vertical displacement increases on the fault, as observed during continuous creep and slip events.

There is not such an evident tendency for azimuthal behavior (Fig. 2a and b); the azimuth oscillated during 19992000, slightly increased during 2001-2003, and diminished with time during 2008-2012, except during December 2009April 2010, which will be discussed later.

However, a significant azimuth change can be seen between Fig. 2a and b. Tilt tends to be more northoriented for the 2008-2012 period. This phenomenon can be related to the subsidence amplitude increase in the recharge area observed for 1993-2009 by Sarychikhina and Glowacka (2015b) (this book).

Three kinds of deformation are shown in Fig. 3. The typical slip event shown on Fig. 3a is characterized by an $R$ increase, related to the extension (subsidence) increase and azimuth decrease, with about one day duration. Triggered by the $M=7.2 \mathrm{HME}$, the slip event shown on Fig. $3 \mathrm{~b}$ is characterized by abrupt $R$ increase, extension (subsidence) increase, and azimuth decrease. This is followed by the slow deformation with the same orientation, similar to the regular slip event, but with smaller magnitude, expected since
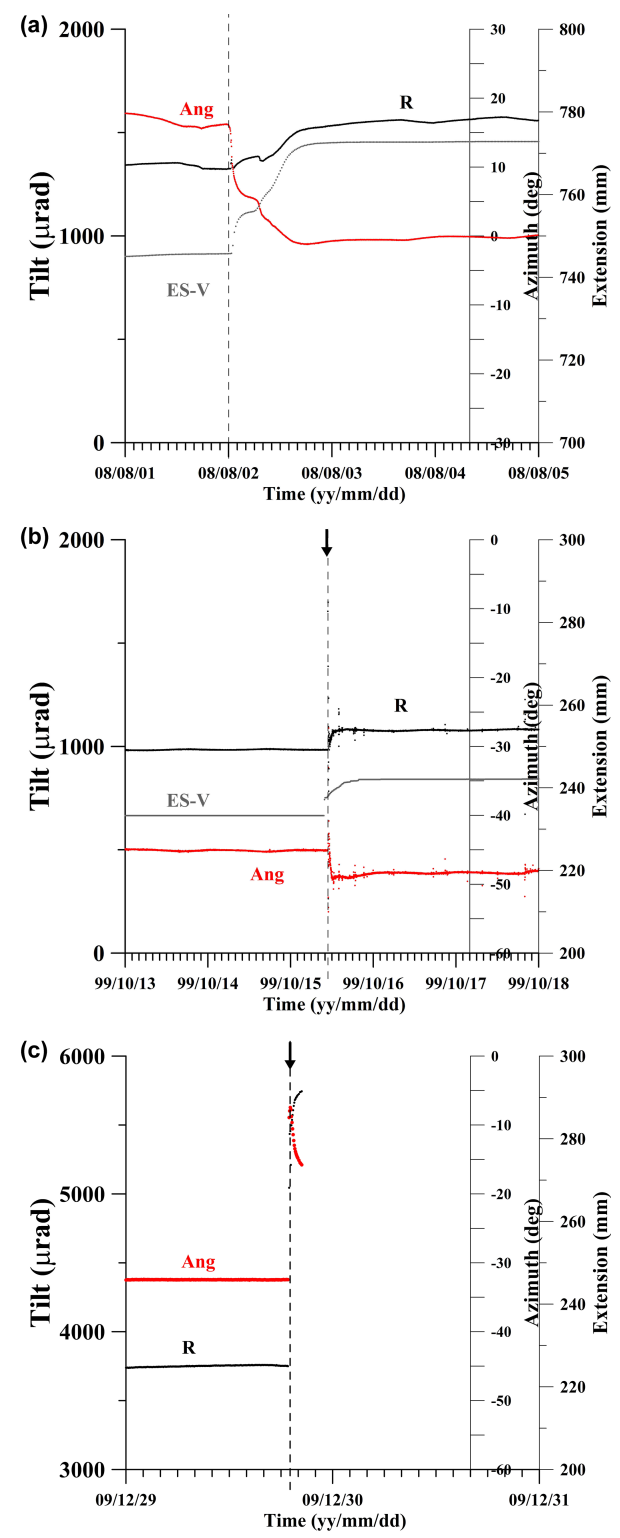

Figure 3. Tilt observations vs. time for episodic slip (a), triggered slip (b) and coseismic slip (c). $R$ is the resultant tilt magnitude in the azimuth direction Ang. $R$ is referred to the left axes, while azimuth Ang is referred to the right axes. Extension ES-V is shown for the period when the creepmeter was working. The vertical arrow indicates the $M=7.21999$ hector Mine earthquake (b) and the $M=5.8,2009$ earthquake (c).

the slip predictable character of deformation suggested by Glowacka et al. (2002). The deformation shown on Fig. 3c was caused by a local $M=5.8$ earthquake and about $1 \mathrm{~h}$ of deformation was recorded after the earthquake before the instrument went out of range. Within the time precision of the tiltmeter (one sample every $4 \mathrm{~min}$ ) the immediate $R$ increase followed by postseismic $R$ increase can be observed. However, the azimuth shows immediate increase and postseismic decrease. 
Although creepmeters were not working during the $M=5.8,2009$ earthquake, Sarychikhina et al. (2015), using data from InSAR and leveling, showed there was subsidence (about $20 \mathrm{~cm}$ ) and slip associated with this earthquake. They suggested that the observed deformation could be caused by triggered aseismic slip on the Saltillo fault or by earthquaketriggered soft sediments subsidence.

\section{Conclusions}

Our results show that the tilt magnitude is proportional to the extension recorded by a creemeter, which may eventually allow to substitute results when one instrument is missing.

Since magnitude and azimuth behaviors are very similar for episodic and triggered slip we suggest that they occur along the same fault segment and the same depth.

However, the different tilt azimuthal behavior for local earthquakes suggests that the slip on the fault has a different behavior, possibly including a horizontal component or/and that the slip was deeper than for episodic slip. More dense instrumentation with a higher frequency of measurements could be useful to confirm this suggestion.

Acknowledgements. This research was sponsored in part by CONACYT, project 105907 and CICESE internal funds.

\section{References}

Camacho Ibarra, E.: Análisis de la deformación vertical del terreno en la región de confluencia del sistema de fallas Cerro Prieto Imperial en el periodo 1962-2001, MSc Thesis, Centro de Investigación Científica y Educación Superior de Ensenada, Ensenada, B.C., Mexico, 135 pp., 2006

Carnec, C. and Fabriol, H.: Monitoring and Modeling Land Subsidence at the Cerro Prieto Geothermal Field, Baja California,Mexico, Using SAR Interferometry, Geophys. Res. Lett., 26, 1211-1214, 1999.

Fabriol, H. and Munguia, L.: Seismic Activity At The Cerro Prieto Geothermal Area (Mexico) From August 1994 To December 1995, And Relationship With Tectonics And Fluid Exploitation, Geophys. Res. Lett., 24, 1807-1810, 1997.

Glowacka, E. and Nava, F. A.: Major earthquake in Mexicali valley, Mexico, and Fluid Extraction at Cerro Prieto Geothermal Field, Bull. Seismol. Soc. Am., 86, 93-105, 1996.

Glowacka, E., González, J., and Fabriol, H.: Recent Vertical deformation in Mexicali Valley and its Relationship with Tectonics, Seismicity and Fluid Operation in the Cerro Prieto Geothermal Field, Pure Appl. Geophys., 156, 591-614, 1999.

Glowacka, E., González, J. J., Nava, F. A., Farfán, F., and Díaz de Cossío, G.: Monitoring Surface Deformations in the Mexicali Valley, B.C., Mexico, Proceedings of Tenth International Symposium on Deformation Measurements, Orange, California, USA, 175-183, 2001.

Glowacka, E., Nava, F. A., Diaz de Cossio, G., Wong, V., and Farfan, F.: Fault slip, Seismicity and Deformation in the Mexicali
Valley (B.C., Mexico) after the 1999 Hector Mine Earthquake ( $M=7.1)$, Bull. Seismol. Soc. Am., 92, 1290-1299, 2002.

Glowacka, E., Sarychikhina, O., and Nava, F. A.: Subsidence and stress change in the Cerro Prieto Geothermal Field, B.C., Mexico, Pure Appl. Geophys., 162, 2095-2110, 2005.

Glowacka, E., Sarychikhina, O., Suárez, F., Nava, F. A., and Mellors, R.: Anthropogenic subsidence in the Mexicali Valley, B.C., Mexico, and the slip on Saltillo Fault, Environ. Earth Sci., 59, 1515-1523, 2010a.

Glowacka, E., Sarychikhina O., Suárez, F., Nava, F. A., Farfan, F., Batani, G., and Garcia-Arthur, M. A.: Anthropogenic subsidence in the Mexicali Valley, B.C., Mexico, caused by the fluid extraction in the Cerro Prieto geothermal Field and the role of faults, Proceedings, World Geothermal Congress, Bali, Indonesia, 2529, 2010b.

Glowacka, E., Sarychikhina, O., Nava, F. A., Suarez, F., Ramirez, J., Guzman, M., Robles, B., and Farfan, F.: Guillermo Diaz De Cossio Batani, Continuous monitoring techniques of fault displacement caused by geothermal fluid extraction in the Cerro Prieto Geothermal Field (Baja California, Mexico), in: Land Subsidence, Associated Hazards and the Role of Natural Resources Development, edited by: Correón-Freyre, D., Cerca, M., and Galowey, D., Land Subsidence, Associated Hazards and the Role of Natural Resources Development, Proceedings of EISOLS 2010, 17-22 October 2010, Querétaro, Mexico, IAHS Publ., 339, 326332, 2010c.

Glowacka, E., Sarychikhina, O., Vazquez-Gonzalez, R., Nava, F. A., García-Hernández, A., Pérez, A., Aguado, C., López-Hernández, M., Farfan, F., Diaz De Cossio, G., and Orozco, L.: Catálogo de eventos de slip registrados con los instrumentos geotérmicos y piezómetros en la cuenca de Cerro Prieto, Reunión Anual Unión Geofísica Mexicana, 31, p. 121, 2011.

Glowacka, E., Sarychikhina, O., Robles, B., Suarez Vidal, F., Ramírez Hernández, J., and Nava, F. A.: Estudio geológico para definir la línea de hundimiento cero y monitorear la subsidencia de los módulos 10, 11 y 12 en el Valle de Mexicali, en el distrito de riego 014, Reporte Final, Rio Colorado, B.C., 2012.

Glowacka, E., Sarychikhina, O., Márquez Ramírez, V. H., Nava, F. A., Farfán, F., and García Arthur, M. A.: Deformation Around the Cerro Prieto Geothermal Field Recorded by the Geotechnical Instruments Network REDECVAM During 1996-2009, WGC 2015, Proceedings CD, Melbourne, Australia, 2015.

González, J., Glowacka, E., Suárez, F., Quiñones, J. G., Guzmán, M., Castro, J. M., Rivera, F., and Félix, M. G.: Movimiento reciente de la Falla Imperial, Mexicali, B. C. Ciencia para todos Divulgare, Universidad Autónoma de Baja California, 6, 4-15, 1998.

Hanssen, R. F.: Radar Interferometry: Data Interpretation and Error Analysis, Kluwer Academic Publishers, Dordrecht, the Netherlands, 328 pp., 2001.

Lira, H. and Arellano, J. F.: Resultados de la nivelación de precisión realizada en 1997, en el campo geotérmico Cerro Prieto, Informe Técnico RE 07/97, Comisión Federal de Electricidad, Residencia de Estudios, México, 28 pp., 1997.

Lomnitz, C., Mooser, F., Allen, C. R., Brune, J. N., and Thatcher, W.: Seismicity and tectonics of the northern Golf of California region, Mexico, preliminary results, Geof. Int., 10, 37-48, 1970.

Majer, E. L. and Mcevilly, T. V.: Seismological Studies at the Cerro Prieto Geothermal Field, 1978-1982, Proc. Fourth Symp. on 
the Cerro Prieto Geothermal Field, Baja California, Mexico, Comisión Federal de Electricidad, Guadalajara, Mexico, 145151, 1981.

Nava, F. A. and Glowacka, E.: Automatic identification of seismic swarms and other spatio-temporal clustering from catalogs, Comput. Geosci., 20, 797-820, 1994.

Nava, F. A. and Glowacka, E.: Fault slip triggering, healing, and viscoelastic afterworking in sediments in the Mexicali_Imperial Valley, Pure Appl. Geophys., 156, 615-629, 1999.

Sarychikhina, O. and Glowacka, E.: Application of DInSAR Stacking Method for Monitoring of Surface Deformation Due to Geothermal Fluids Extraction in the Cerro Prieto Geothermal Field, Baja California, Mexico, Proceedings, World Geothermal Congress, Melbourne, Australia, 2015a.

Sarychikhina, O. and Glowacka, E.: Spacio-temporal evaluation of aseismic grond deformation in the Mexicali Valley (Baja California, Mexico) from 1993 to 2010, using differential SAR interferometry, NISOLS, Nagoya, Japan, 2015 b.

Sarychikhina, O., Glowacka, E., Mellors, R., and Suárez-Vidal, F.: Land subsidence in the Cerro Prieto Geothermal Field, Baja California, Mexico, from 1994 to 2005. An integrated analysis of DInSAR, leveling and geological data, J. Volcanol. Geoth. Res., 204, 76-90, 2011.
Sarychikhina, O., Glowacka, E., Robles, B., Nava, F. A., and Guzmán, M.: Estimation of Seismic and Aseismic Deformation in Mexicali Valley, Baja California, Mexico, in the 2006-2009 Period, Using Precise Leveling, DInSAR, Geotechnical Instruments Data, and Modeling, Pure Appl. Geophys., 172, 31393162, 2015.

Suárez-Vidal, F., Mendoza-Borunda, R., Naffarrete-Zamarripa, L. M., Ramírez, J., and Glowacka, E.: Shape and dimensions of the Cerro Prieto pull-apart basin, Mexicali, Baja California, Mexico, based on the regional seismic record and surface structures, Int. Geol. Rev., 50, 636-649, 2008.

Trugman, D. T., Borsa, A. A., and Sandwell, D. T.: Did stresses from the Cerro Prieto Geothermal Field influence the El MayorCucapah rupture sequence?, Geophys. Res. Lett., 41, 8767-8774, 2014.

Velasco, J.: Levantamiento Gravimétrico, Zona Geotérmica de Mexicali, Baja California. Technical Report, Consejo de Recursos Naturales no Renovables, 55 pp., 1963. 